\title{
Efek Mediasi Organizational Citizenship Behavior diantara Kecerdasan Emosional dan Kecerdasan Spiritual terhadap Kinerja Tenaga Kependidikan Universitas Negeri Malang
}

\author{
Fatikha Floressya Arifin ${ }^{a} *$ \\ ${ }^{a}$ Universitas Negeri Malang, Malang, Jawa Timur, Indonesia
}

\section{INFORMASI ARTIKEL}

\section{Article history:}

Dikirim tanggal: 11 Maret 2019

Revisi pertama tanggal: 13 Maret 2019

Diterima tanggal: 30 Juli 2019

Tersedia online tanggal: 07 Agustus 2019

Keywords: organizational citizenship behavior, emotional intelligence, spiritual intelligence, job performance

\begin{abstract}
The aim of this study was to explain the mediating effects of Organizational Citizenship Behavior (OCB) between emotional intelligence and spiritual intelligence on the performance of educational staff at the State University of Malang. In addition, this research is also aims to determine the extent of the influence of these three variables on performance. This type of research is quantitative with a survey method carried out for education staff at the State University of Malang. The sampling technique is proportional random sampling. The results showed that there was a partial mediating effect between emotional intelligence and spiritual intelligence on the performance of educational staff at the State University of Malang. The three variables also have a significant effect on the performance of education staff at State University of Malang.
\end{abstract}

\section{INTISARI}

Tujuan dari penelitian ini adalah untuk menjelaskan efek mediasi Organizational Citizenship Behavior (OCB) diantara kecerdasan emosional dan kecerdasan spiritual terhadap kinerja tenaga kependidikan Universitas Negeri Malang. Selain itu, penelitian juga bertujuan untuk mengetahui sejauh mana pengaruh ketiga variabel tersebut terhadap kinerja. Jenis penelitian ini adalah kuantitatif dengan metode survei yang dilakukan kepada para tenaga kependidikan di Univeritas Negeri Malang. Teknik pengambilan sampelnya adalah proportional random sampling. Hasil penelitian menunjukkan bahwa, terdapat efek mediasi parsial, diantara kecerdasan emosional dan kecerdasan spiritual terhadap kinerja tenaga kependidikan Universitas Negeri Malang. Ketiga variabel tersebut juga berpengaruh signifikan terhadap kinerja tenaga kependidikan di Universitas Negeri Malang.

2019 FIA UB. All rights reserved.

\section{Pendahuluan}

Refomasi Birokrasi telah dan sedang berlangsung pada Kementerian Riset, Teknologi dan Pendidikan Tinggi, termasuk juga pada Universitas Negeri Malang (UM) yang telah berstatus sebagai Badan Layanan
Umum (BLU). Peningkatan kualitas layanan menjadi tujuan penting dalam pengembangan kelembagaan UM.

Berbagai layanan publik yang berhubungan dengan pihak internal dan eksternal pada dasarnya dapat dirangkum ke dalam lima unit layanan, yakni layanan

\footnotetext{
* Corresponding author. Tel.: +62-852-3212-1917; e-mail: fatikha@gmail.com
} 
akademik, layanan kemahasiswaan, layanan kepegawaian, layanan keuangan, layanan umum. Untuk mendukung seluruh layanan tersebut diperlukan adanya dukungan dan profesionalisme dari tenaga kependidikan yang dimiliki oleh Universitas Negeri Malang.

Teori Perilaku Organisasi yang digagas oleh Robbins (2008) menjelaskan mengenai bagaimana kinerja organisasi dapat diciptakan dan diprediksi bergantung pada sebuah input yang terdiri dari bagaimana faktor di level individu, kelompok maupun organisasi mampu memahami dan mengatur sumber daya manusia sebagai aset organisasi.

Hal paling utama yang mampu berperan dalam memprediksi sebuah kinerja baik dilevel individu, kelompok, maupun organisasi adalah individu didalam organisasi yang disebut dengan pekerja. Pekerja tak bisa lepas dari bagaimana keyakinan, sikap, dan pengalamannya dalam menyelesaikan pekerjaannya (Kinicki \& Fugate, 2013). Jika sikap, keyakinan, dan pengalaman yang dimiliki pegawai tergolong rendah maka output yang berupa performansi atau kinerja pun akan ikut rendah. Sebaliknya, jika sikap, keyakinan, dan pengalaman yang dimiliki pegawai tergolong tinggi terhadap pekerjaannya maka akan diikuti oleh performansi atau kinerja yang tinggi pula.

Kemampuan kerja yang sempurna saja tidak cukup untuk memperlihatkan kinerja pegawai, tetapi juga kualitas pribadi, seperti inisiatif dan empati, adaptabilitas dan kemampuan persuasi. Menurut Daniel Goleman (2000:7) peran IQ atau kecerdasan intelektual dalam keberhasilan di dunia kerja hanya menempati posisi kedua sesudah kecerdasan emosi dalam menentukan peraihan prestasi puncak dalam pekerjaan. Salah satu bentuk kecerdasan lain yang saat ini tengah populer adalah kecerdasan spiritual. Kecerdasan spiritual memungkinkan seseorang untuk berpikir kreatif, berwawasan jauh, membuat atau bahkan mengubah aturan, yang membuat orang tersebut dapat bekerja lebih baik.

Pengembangan kecerdasan emosional dan kecerdasan spiritual ini sesuai dengan prinsip dan tujuan UM sebagai The Learning University. Prinsip-prinsip dasar yang dianut UM adalah prinsip religius, akademik, inovatif dan humanis. Sedangkan tujuan penggunaan The Learning University diantaranya adalah agar UM tumbuh dan berkembang menjadi organisasi belajar (learning organization) untuk meningkatkan sistem dan layanan yang memadai dan masyarakat UM selalu dalam nuansa belajar dan saling membelajarkan.

Selain faktor kecerdasan emosional dan kecerdasan spiritual, menurut Basu, Pradhan dan Tewari (2017), Organizational Citizenship Behavior (OCB) juga mampu berperan dalam membentuk kinerja seseorang. Partisipasi sukarela dalam OCB telah dianggap sebagai tanda dedikasi pada organisasi, oleh karena itu OCB mempengaruhi kinerja secara keseluruhan (Organ, Podsakoff, \& Scott B MacKenzie, 2006). OCB mampu berperan sebagai mediator dalam pembentukan kinerja (Andrew \& Cazares, 2015). Dalam penelitian tersebut ditemukan bahwa OCB memediasi hubungan antara motivasi pelayanan publik terhadap kinerja pada pegawai negeri di Meksiko. Pegawai memperlihatkan OCB yang diasosiasikan dengan performansi organisasi publik yang lebih baik, karena motivasi pelayanan publik yang tinggi.

Berdasarkan uraian di atas, maka penelitian ini dilakukan untuk menjelaskan efek mediasi Organizational Citizenship Behavior (OCB) diantara kecerdasan emosional dan kecerdasan spiritual terhadap kinerja tenaga kependidikan Universitas Negeri Malang. Selain itu, penelitian juga bertujuan untuk mengetahui sejauh mana pengaruh ketiga variabel tersebut terhadap kinerja.

\section{Teori}

\subsection{Kecerdasan Emosional}

Menurut Robbin (2001), kecerdasan emosional adalah:

Kecerdasan emosional merupakan sekumpulan keahlian kognitif, kemampuan dan kompetensi yang mempengaruhi kemampuan personal untuk meraih keberhasilan dalam mengatasi tuntutan dan tekanan lingkungan.

Dari pendapat diatas dapat diartikan bahwa kecerdasan emosional perlu dimiliki seorang pegawai. Pikiran, perkataan dan bahkan perilaku seorang pegawai akan terpengaruh oleh kondisi emosionalnya. Seorang pegawai yang mampu mengekspresikan emosinya secara tepat dan memiliki kondisi emosional yang terkontrol akan dapat bermanfaat dalam pekerjaan dan juga kehidupannya sehari-hari.

Kecerdasan emosional dikaitkan dengan sistem manajemen sumber daya manusia, misalnya untuk perencanaan dan pengembangan pelatihan. Pelatihan tersebut hasil akhirnya diharapkan dapat meningkatkan kinerja pegawai. Studi - studi menunjukkan bahwa seorang eksekutif atau profesional yang secara teknik unggul dan memiliki EQ yang tinggi adalah orang orang yang mampu mengatasi konflik, melihat kesenjangan yang perlu dijembatani atau diisi, melihat hubungan yang tersembunyi yang menjanjikan peluang, berinteraksi, penuh pertimbangan untuk menghasilkan yang lebih berharga, lebih siap, lebih cekatan, dan lebih cepat dibandingkan orang lain.

\subsection{Kecerdasan Spiritual}

Menurut Zohar dan Marshall (2007), kecerdasan spiritual adalah sebagai berikut:

Kecerdasan spiritual diartikan sebagai kecerdasan yang bertumpu pada bagian dalam diri yang berhubungan dengan kearifan diluar ego atau jiwa 
kesadaran. Sebagai kecerdasan yang senantiasa dipergunakan bukan hanya untuk mengetahui nilainilai yang ada, melainkan juga untuk secara kreatif menemukan nilai - nilai baru dalam kehidupan. Jadi seseorang menghadapi persoalan makna atau nilai (value) guna menempatkan perilaku dan hidup dalam konteks yang lebih luas.

Dapat diartikan bahwa kecerdasan spiritual merupakan landasan bagi kecerdasan lainnya. Pegawai dengan kecerdasan spiritual tinggi akan mampu memberi makna positif pada masalah yang dialaminya. Jika pegawai telah mampu memberi makna positif dari masalah yang dialami, maka pegawai tersebut juga akan mampu untuk membangkitkan jiwanya dan melakukan perilaku yang positif pula.

\subsection{Organizational Citizenship Behavior (OCB)}

Organ (1988) mendefinisikan Organizational Citizenship Behavior (OCB) sebagai berikut:

Pekerjaan yang berhubungan dengan perilaku yang tidak mengikat, tidak berkaitan dengan sistem reward formal yang diberikan organisasi, dan secara keseluruhan meningkatkan efektivitas fungsi organisasi.

OCB bersifat bebas dan sukarela, perilaku ini merupakan pilihan personal, tidak diharuskan oleh deskripsi jabatan yang secara jelas dituntut berdasarkan kontrak pegawai dengan organisasi. Pegawai yang memiliki OCB akan secara sukarela menolong teman, dan melakukan tugas ekstra diluar job description-nya.

\subsection{Dinamika antara Kecerdasan Emosional, Kecerdasan Spiritual, dan OCB dalam Membentuk Kinerja}

Goleman (2005) menyatakan bahwa kecerdasan emosional (EQ) yang dapat ditunjukkan melalui interaksi dalam diri individu mengenai bagaimana individu menerima dan memproses sebuah stimulus yang ia terima dan kemudian mengekspresikannya merupakan bentuk dari sebuah sikap. Selain EQ, Podsakoff et al., (2000) juga menyatakan bahwa Organizational Citizenship Behavior (OCB) juga merupakan sebuah sikap tanpa syarat yang ditunjukkan oleh individu kepada orang lain, kelompok, maupun organisasi. Berbeda dengan OCB dan EQ, SQ merupakan bagian dari keyakinan seseorang yang berperan dalam pengambilan sebuah keputusan untuk berperilaku (Zohar \& Marshall, 2007).

Ketiga variabel tersebut menurut teori perilaku organisasi mampu menjadi prediktor dalam memahami dan mengatur individu itu sendiri, kelompok, dan organisasi yang dapat secara tidak langsung mempengaruhi kinerja baik kinerja individu, kelompok, maupun organisasi. Berdasarkan penjelasan tersebut maka dapat dikatakan bahwa EQ dan SQ dalam diri seseorang selalu mengalami interaksi pada diri pegawai dalam memunculkan perilaku dan berinteraksi dengan sosial. Hal tersebut merupakan faktor yang secara langsung bisa membedakan kualitas pekerjaan dari masing-masing pekerja menjadi bervariasi. Diagram dari teori perilaku organisasi menunjukkan bahwa prediktor yang baik dalam sebuah organisasi akan mampu menghasilkan performansi yang baik pula.

Jika dikaitkan dengan pelayanan yang diberikan oleh tenaga kependidikan sebagai aparatur negara terhadap dosen dan mahasiswa sebagai subjek yang harus dilayani, maka dapat diprediksi jika sikap, keyakinan, dan pengalaman yang dimiliki tenaga kependidikan tergolong rendah maka output yang berupa performansi atau kinerja pun akan ikut rendah. Sebaliknya, jika sikap, keyakinan, dan pengalaman yang dimiliki tenaga kependidikan tergolong tinggi terhadap pekerjaannya maka akan diikuti oleh performansi atau kinerja yang tinggi pula. Sesuai dengan teori perilaku organisasi bahwa adanya perbedaan kualitas pekerja yang diakibatkan oleh rendahnya EQ dan SQ dapat mempengaruhi kinerja individu, kelompok, maupun organisasi secara langsung. Akan tetapi, hal itu mampu diperkuat oleh adanya adanya OCB yang berfungsi sebagai mediator (Andrew \& Leon-Cazares, 2015). Baron \& Kenny (1986) menyatakan bahwa variabel mediator adalah variabel yang mampu mempengaruhi kuat lemahnya hubungan antara variabel bebas dan tergantung. Maka peranan dari mediator dapat dikatakan efektif jika mampu membuat pengaruh dari variabel bebas terhadap variabel tergantung lebih besar jika dibandingkan dengan hubungan langsung antara variabel bebas dan tergantung tanpa adanya peran mediator. Hal ini menunjukkan bahwa adanya OCB sebagai mediator mampu berfungsi sebagai penguat hubungan antara SQ dan EQ sebagai variabel bebas terhadap kinerja sebagai variabel tergantung. Pernyataan tersebut dapat diartikan bahwa OCB yang tinggi mampu mempengaruhi hubungan antara SQ dan EQ terhadap kinerja menjadi lebih tinggi jika dibandingkan dengan adanya hubungan tanpa OCB.

\section{Metode Penelitian}

Berdasarkan jenis pendekatannya, maka penelitian ini termasuk dalam penelitian kuantitatif yang bertujuan untuk mendeskripsikan dan menganalisis efek mediasi Organizational Citizenship Behavior (OCB) diantara kecerdasan emosional, dan kecerdasan spiritual terhadap kinerja tenaga kependidikan Universitas Negeri Malang. Metode yang digunakan adalah metode survei yang dilakukan kepada 300 orang tenaga kependidikan Universitas Negeri Malang, menggunakan teknik proportional random sampling.

Uji validitas dan reliabilitas dilakukan pada instrumen penelitian sehingga diperoleh hasil penelitian dengan tingkat ketepatan dan konsistensi yang tinggi. Hasil uji validitas menunjukkan bahwa semua nilai 
korelasi item bernilai diatas 0.3 pada semua item instrumen penelitian. Dan hasil uji reliabilitas menunjukkan bahwa nilai koefisien Alpha Cronbach lebih besar dari 0,60. Jadi dapat dinyatakan bahwa instrumen penelitian yang digunakan adalah valid dan reliabel.

Model yang digunakan dalam penelitian ini adalah kausalitas atau hubungan pengaruh, untuk menguji hipotesis yang diajukan dalam penelitian ini maka digunakan Teknik Structural Equation Modeling (SEM) yang dioperasikan melalui program AMOS 20.

Uji asumsi juga dilakukan untuk mengetahui normalitas, tidak terjadi outlier, dan linieritas hubungan antar variabel. Dari uji asumsi melalui uji normalitas diketahui bahwa variabel dalam penelitian ini tidak terdistribusi normal. Namun demikian, berdasarkan dalil limit pusat jika sampel semakin besar maka statistik akan berdistribusi normal. Dengan besar sampel 300 maka data studi ini dipandang memenuhi dalil limit pusat, sehingga asumsi normalitas data tidak bersifat kritis dan dapat diabaikan. Berdasarkan uji asumsi outlier disimpulkan bahwa semua titik observasi bukan merupakan outlier. Dengan demikian asumsi outlier terpenuhi. Dan melalui uji linieritas, diketahui bahwa ketujuh hubungan yang dibangun dalam penelitian ini menujukkan bahwa model linier signifikan (sig model linier < 0.05), yang mengindikasikan bahwa asumsi linieritas hubungan antar variabel dalam penelitian ini terpenuhi.

Data dikumpulkan terutama dengan metode kuesioner dan didukung dengan metode dokumentasi, wawancara dan observasi. Variabel dalam penelitian ini terdiri dua kelompok variabel, yaitu variabel eksogen yang terdiri dari Kecerdasan Emosional (X1) dan Kecerdasan Spiritual (X2) serta variabel endogen yang terdiri dari variabel Organizational Citizenship Behavior (Z), dan Kinerja Tenaga Pendidikan (Y).

Model teoritis pada kerangka konseptual penelitian dikatakan fit jika didukung oleh data empirik. Hasil pengujian goodness of fit overall model memperlihatkan bahwa lima dari tujuh kriteria, yaitu CMIN/DF, RMSEA, GFI, TLI dan CFI menunjukkan model baik. Menurut Arbuckle \& Wothke (1999), kriteria terbaik yang digunakan sebagai indikasi kebaikan model adalah nilai Chi Square/ DF kurang dari 2, dan RMSEA di bawah 0.08. Pada penelitian ini, nilai CMIN/DF dan RMSEA telah memenuhi nilai cut off, maka model SEM pada penelitian ini cocok dan layak digunakan, sehingga bisa dilakukan interpretasi guna pembahahasan lebih lanjut.

\section{Hasil Penelitian dan Pembahasan}

\subsection{Gambaran Umum Responden}

Responden dalam penelitian ini sejumlah 300 orang berasal dari 2 Biro, 8 Fakultas, 2 Lembaga dan 5 UPT di Universitas Negeri Malang. Gambaran responden berdasarkan jenis kelamin, kelompok usia, pendidikan, masa kerja, dan unit kerja dapat dilihat pada tabel berikut ini.

Tabel 1 Karakteristik Responden Penelitian

\begin{tabular}{|c|c|c|c|}
\hline Karakteristik & Kriteria & $\begin{array}{c}\text { Frekuensi } \\
\text { (orang) }\end{array}$ & $\begin{array}{c}\text { Persentase } \\
(\%)\end{array}$ \\
\hline \multirow[t]{2}{*}{ Gender } & Laki-Laki & 200 & 66.7 \\
\hline & Perempuan & 100 & 33.3 \\
\hline \multirow{4}{*}{ Usia } & 21-30 tahun & 63 & 21.0 \\
\hline & $31-40$ tahun & 113 & 37.7 \\
\hline & 41-50 tahun & 73 & 24.3 \\
\hline & Diatas 50 tahun & 51 & 17.0 \\
\hline \multirow[t]{5}{*}{ Pendidikan } & Diploma & 20 & 6.7 \\
\hline & Lainnya & 15 & 5.0 \\
\hline & Magister & 19 & 6.3 \\
\hline & Sarjana & 160 & 53.3 \\
\hline & SMA/Sederajat & 86 & 28.7 \\
\hline \multirow[t]{4}{*}{ Masa Kerja } & $1-5$ tahun & 80 & 26.7 \\
\hline & 11-15 tahun & 60 & 20.0 \\
\hline & 6-10 tahun & 85 & 28.3 \\
\hline & $\begin{array}{l}\text { Lebih dari } 15 \\
\text { tahun }\end{array}$ & 75 & 25.0 \\
\hline \multirow[t]{18}{*}{ Unit Kerja } & Biro AKPIK & 20 & 6.7 \\
\hline & Biro UK & 110 & 36.7 \\
\hline & FE & 17 & 5.7 \\
\hline & FIK & 9 & 3.0 \\
\hline & FIP & 15 & 5.0 \\
\hline & FIS & 8 & 2.7 \\
\hline & FMIPA & 18 & 6.0 \\
\hline & FPPsi & 3 & 1.0 \\
\hline & FS & 22 & 7.3 \\
\hline & FT & 21 & 7.0 \\
\hline & LP2M & 6 & 2.0 \\
\hline & LP3 & 7 & 2.3 \\
\hline & Pacasarjana & 9 & 3.0 \\
\hline & UPT Perpus & 10 & 3.3 \\
\hline & UPT P2LP & 3 & 1.0 \\
\hline & UPT P2P & 2 & 0.7 \\
\hline & UPT PTIK & 16 & 5.3 \\
\hline & UPT SPM & 4 & 1.3 \\
\hline
\end{tabular}

Sumber: Hasil analisis, 2016

\subsection{Pengujian Hipotesis}

Pada bagian pertama analisis SEM adalah interpretasi model pengukuran atau measurement model. Koefisien measurement model atau disebut loading factor menyatakan besaran/ kontribusi indikator sebagai pengukur variabel. Indikator dengan Loading factor tertinggi mengindikasikan bahwa indikator tersebut sebagai pengukur terkuat variabel yang diukur. Indikator dinyatakan signifikan sebagai pengukur variabel jika nilai $P$-value $<0.05$, atau indikator dinyatakan fix. Adapun syarat ketentuan reliabilitas yaitu $\mathrm{CR} \geq 0.70$. dan $\mathrm{VE} \geq 0.50$.

Tabel 2 Model Pengukuran Variabel Kecerdasan Emosional (X1)

\begin{tabular}{|c|c|c|c|}
\hline Indikator & $\begin{array}{c}\text { Loading } \\
\text { Factor }\end{array}$ & $P$-value & Kesimpulan \\
\hline $\begin{array}{c}\text { Self emotion } \\
\text { appraisal (X1.1) }\end{array}$ & 0,739 & Fix & Signifikan \\
\hline
\end{tabular}




\begin{tabular}{|c|c|c|l|}
\hline Indikator & $\begin{array}{c}\text { Loading } \\
\text { Factor }\end{array}$ & $P$-value & Kesimpulan \\
\hline $\begin{array}{c}\text { Others' emotion } \\
\text { appraisal (X1.2) }\end{array}$ & 0,405 & 0.000 & Signifikan \\
\hline $\begin{array}{c}\text { Use of emotion } \\
\text { (X1.3) }\end{array}$ & 0,755 & 0.000 & Signifikan \\
\hline $\begin{array}{c}\text { Regulation of } \\
\text { emotion (X1.4) }\end{array}$ & 0,683 & 0.000 & Signifikan \\
\hline CR & \multicolumn{3}{|c|}{0.889} \\
\hline VE & \multicolumn{3}{|c|}{0.678} \\
\hline
\end{tabular}

Sumber: Hasil analisis, 2016

Tabel 3 Model Pengukuran Variabel Kecerdasan Spiritual (X2)

\begin{tabular}{|c|c|c|c|}
\hline Indikator & $\begin{array}{c}\text { Loading } \\
\text { Factor }\end{array}$ & P-value & Kesimpulan \\
\hline $\begin{array}{c}\text { Mutlak jujur } \\
\text { (X2.1) }\end{array}$ & 0.765 & 0.000 & Signifikan \\
\hline $\begin{array}{c}\text { Keterbukaan } \\
\text { (X2.2) }\end{array}$ & 0.727 & 0.000 & Signifikan \\
\hline $\begin{array}{c}\text { Pengetahuan Diri } \\
\text { (X2.3) }\end{array}$ & 0.832 & 0.000 & Signifikan \\
\hline $\begin{array}{c}\text { Fokus pada } \\
\text { Kontribusi } \\
\text { (X2.4) }\end{array}$ & 0.803 & Fix & Signifikan \\
\hline $\begin{array}{c}\text { Spiritual non- } \\
\text { dogmatis (X2.5) }\end{array}$ & 0.772 & 0.000 & Signifikan \\
\hline CR & \multicolumn{3}{|c|}{0.966} \\
\hline VE & 0.849 & \\
\hline
\end{tabular}

Sumber: Hasil analisis, 2016

Tabel 4 Model Pengukuran Variabel Organizational Citizenship Behavior (Z)

\begin{tabular}{|c|c|c|c|}
\hline Indikator & $\begin{array}{c}\text { Loading } \\
\text { Factor }\end{array}$ & $\begin{array}{c}P- \\
\text { value }\end{array}$ & Kesimpulan \\
\hline Altruism (Z1) & 0.681 & 0.000 & Signifikan \\
\hline Courtesy (Z2) & 0.724 & 0.000 & Signifikan \\
\hline Civic virtue (Z3) & 0.641 & 0.000 & Signifikan \\
\hline Sportmanship (Z4) & 0.538 & 0.000 & Signifikan \\
\hline $\begin{array}{c}\text { Conscientiounsness } \\
\text { (Z5) }\end{array}$ & 0.665 & Fix & Signifikan \\
\hline CR & \multicolumn{3}{|c|}{0.919} \\
\hline VE & \multicolumn{3}{|c|}{0.695} \\
\hline
\end{tabular}

Sumber: Hasil analisis, 2016

Tabel 5 Model Pengukuran Variabel Kinerja Tenaga Kependidikan (Y)

\begin{tabular}{|c|c|c|c|}
\hline Indikator & $\begin{array}{c}\text { Loading } \\
\text { Factor }\end{array}$ & $P$-value & Kesimpulan \\
\hline Kualitas (Y.1) & 0.793 & Fix & Signifikan \\
\hline Kuantitas (Y.2) & 0.861 & 0.000 & Signifikan \\
\hline $\begin{array}{c}\text { Ketepatan waktu } \\
\text { (Y.3) }\end{array}$ & 0.782 & 0.000 & Signifikan \\
\hline Efektifitas (Y.4) & 0.761 & 0.000 & Signifikan \\
\hline $\begin{array}{c}\text { Kemandirian } \\
\text { (Y.5) }\end{array}$ & 0.571 & 0.000 & Signifikan \\
\hline
\end{tabular}

\begin{tabular}{|c|c|c|c|}
\hline Indikator & $\begin{array}{c}\text { Loading } \\
\text { Factor }\end{array}$ & P-value & Kesimpulan \\
\hline Komitmen (Y.6) & 0.836 & 0.000 & Signifikan \\
\hline
\end{tabular}
Sumber: Hasil analisis, 2016

Pada bagian kedua analisis SEM adalah interpretasi model struktural atau structural model. Model struktural menyajikan hubungan antar variabel penelitian koefisien structural model menyatakan besaran hubungan antara variabel satu terhadap variabel lainnya. Adanya pengaruh yang signifikan antar variabel satu terhadap variabel lainnya, jika nilai P-value < 0.05. Dalam SEM dikenal dua pengaruh yaitu pengaruh langsung (direct effect), serta pengaruh tidak langsung (indirect effect).

Tabel 6 Model Struktural Hasil SEM:

Pengaruh Langsung

\begin{tabular}{|c|l|c|c|c|}
\hline No & \multicolumn{1}{|c|}{ Hubungan } & Koefisien & $P$-value & Kesimpulan \\
\hline 1 & $\mathrm{X} 1 \rightarrow \mathrm{Z}$ & 0.341 & 0.003 & Signifikan \\
\hline 2 & $\mathrm{X} 2 \rightarrow \mathrm{Z}$ & 0.513 & 0.000 & Signifikan \\
\hline 3 & $\mathrm{X} 1 \rightarrow \mathrm{Y}$ & 0.208 & 0.014 & Signifikan \\
\hline 4 & $\mathrm{X} 2 \rightarrow \mathrm{Y}$ & 0.590 & 0.000 & Signifikan \\
\hline 5 & $\mathrm{Z} \rightarrow \mathrm{Y}$ & 0.187 & 0.019 & Signifikan \\
\hline
\end{tabular}

Sumber: Hasil analisis, 2018

Tabel 7 Model Struktural Hasil SEM: Pengaruh Tidak Langsung (Efek Mediasi)

\begin{tabular}{|c|c|c|}
\hline $\begin{array}{c}\text { Pengaruh Tidak } \\
\text { Langsung }\end{array}$ & $\begin{array}{c}\text { Koefisien } \\
\text { Pengaruh Tidak } \\
\text { Langsung }\end{array}$ & Keterangan \\
\hline $\mathrm{X} 1 \rightarrow \mathrm{Z} \rightarrow \mathrm{Y}$ & 0.064 & Signifikan \\
\hline $\mathrm{X} 2 \rightarrow \mathrm{Z} \rightarrow \mathrm{Y}$ & 0.096 & Signifikan \\
\hline
\end{tabular}

Sumber: Hasil analisis, 2018

Ket: * signifikan, ns tidak signifikan

Berdasarkan pembuktian hipotesis di atas, dapat disusun kesimpulan sebagaimana tabel 8, dibawah ini:

Tabel 8 Hasil Pembuktian Hipotesis

\begin{tabular}{|c|l|c|}
\hline Hipotesis & \multicolumn{1}{|c|}{ Uraian } & Hasil \\
\hline H1 & $\begin{array}{l}\text { Kecerdasan emosional (EQ) } \\
\text { berpengaruh terhadap } \\
\text { Organizational Citizenship } \\
\text { Behavior (OCB) }\end{array}$ & Diterima \\
\hline H2 & $\begin{array}{l}\text { Kecerdasan spiritual (SQ) } \\
\text { berpengaruh terhadap } \\
\text { Organizational Citizenship } \\
\text { Behavior (OCB) }\end{array}$ & Diterima \\
\hline H3 & $\begin{array}{l}\text { Kecerdasan emosional (EQ) } \\
\text { berpengaruh terhadap kinerja } \\
\text { tenaga kependidikan } \\
\text { Universitas Negeri Malang }\end{array}$ & Diterima \\
\hline H4 & $\begin{array}{l}\text { Kecerdasan spiritual (SQ) } \\
\text { berpengaruh terhadap kinerja } \\
\text { tenaga kependidikan } \\
\text { Universitas Negeri Malang }\end{array}$ & Diterima \\
\hline H5 & $\begin{array}{l}\text { Organizational Citizenship } \\
\text { Behavior } \text { (OCB) berpengaruh }\end{array}$ & Diterima \\
\hline
\end{tabular}




\begin{tabular}{|c|l|c|}
\hline Hipotesis & \multicolumn{1}{|c|}{ Uraian } & Hasil \\
\hline & $\begin{array}{l}\text { terhadap kinerja tenaga } \\
\text { kependidikan Universitas } \\
\text { Negeri Malang }\end{array}$ & \\
\hline H6 & $\begin{array}{l}\text { Organizational Citizenship } \\
\text { Behavior (OCB) memiliki } \\
\text { efek mediasi diantara } \\
\text { kecerdasan emosional dan } \\
\text { kecerdasan spiritual terhadap } \\
\text { kinerja tenaga kependidikan } \\
\text { Universitas Negeri Malang }\end{array}$ & Diterima \\
\hline
\end{tabular}

Sumber: Hasil analisis, 2018

\subsection{Pembahasan}

Kecerdasan emosional berpengaruh secara positif dan signifikan terhadap Organizational Citizenship Behavior (OCB). Terbukti dari koefisien struktural sebesar 0.341 , dan p-value 0.003 yang artinya bahwa kecerdasan emosional yang meningkat akan secara signifikan meningkatkan Organizational Citizenship Behavior (OCB). Skor rata-rata variabel kecerdasan emosional adalah 3.88 (kategori tinggi) dan rata-rata variabel Organizational Citizenship Behavior (OCB) 3.90 (kategori tinggi). Dapat disimpulkan bahwa jika kecerdasan emosional tenaga kependidikannya tinggi, maka akan meningkatkan kepedulian sosialnya. Tingkat kepedulian sosial yang juga termasuk menghormati hak orang lain akan meningkatkan Organizational Citizenship Behavior (OCB) diantara para tenaga kependidikan. Penelitian ini mendukung penelitian sebelumnya terkait pengaruh kecerdasan emosional terhadap Organizational Citizenship Behavior (OCB) dari Garcia \& Ocampo (2016) serta Anwar et al., (2017).

Kecerdasan spiritual berpengaruh secara positif dan signifikan terhadap Organizational Citizenship Behavior (OCB). Terbukti dari koefisien struktural sebesar 0.513, dan p-value 0.000 yang artinya bahwa kecerdasan spiritual yang meningkat akan secara signifikan meningkatkan Organizational Citizenship Behavior (OCB). Skor rata-rata variabel kecerdasan spiritual adalah 4.21 (kategori sangat tinggi) dan rata-rata variabel Organizational Citizenship Behavior (OCB) 3.90 (kategori tinggi). Dapat disimpulkan bahwa jika kecerdasan spiritual tenaga kependidikannya tinggi, maka akan meningkatkan keyakinannya untuk jujur dan pengetahuan dirinya. Tingkat keyakinan untuk jujur dan pengetahuan dirinya yang juga termasuk menghormati hak orang lain akan meningkatkan Organizational Citizenship Behavior (OCB) diantara para tenaga kependidikan. Penelitian ini mendukung penelitian sebelumnya terkait pengaruh kecerdasan spiritual terhadap Organizational Citizenship Behavior (OCB) dari Moosapour, et al (2013) serta Anwar \& Osman-Gani (2015).
Kecerdasan emosional berpengaruh secara positif dan signifikan terhadap kinerja tenaga kependidikan. Terbukti dari koefisien struktural sebesar 0.208, dan $p$ value 0.014 yang artinya bahwa kecerdasan emosional yang meningkat akan secara signifikan meningkatkan kinerja tenaga kependidikan. Skor rata-rata variabel kecerdasan emosional adalah 3.88 (kategori tinggi) dan rata-rata variabel kinerja tenaga kependidikan 4.13 (kategori tinggi). Dapat disimpulkan bahwa jika kecerdasan emosional tenaga kependidikannya tinggi, maka semangat mereka untuk berusaha sebaik mungkin juga tinggi. Dibutuhkan semangat untuk terus menerus berusaha sebaik mungkin dan bekerja sepenuh hati demi peningkatan kinerja. Penelitian ini mendukung penelitian sebelumnya terkait pengaruh kecerdasan emosional terhadap kinerja tenaga kependidikan dari Dhani \& Sharma (2017) serta Anggraini (2017).

Kecerdasan spiritual berpengaruh secara positif dan signifikan terhadap kinerja tenaga kependidikan. Terbukti dari koefisien struktural sebesar 0.590, dan $p$ value 0.000 yang artinya bahwa kecerdasan spiritual yang meningkat akan secara signifikan meningkatkan kinerja tenaga kependidikan. Skor rata-rata variabel kecerdasan spiritual adalah 4.21 (kategori sangat tinggi) dan rata-rata variabel kinerja tenaga kependidikan 4.13 (kategori tinggi). Dapat disimpulkan bahwa jika kecerdasan spiritual tenaga kependidikannya tinggi, maka akan meningkatkan keyakinannya untuk jujur dan pengetahuan dirinya. Tingkat keyakinan untuk jujur dan pengetahuan diri yang juga termasuk bekerja sepenuh hati akan meningkatkan kinerja tenaga kependidikan. Penelitian ini mendukung penelitian sebelumnya terkait pengaruh kecerdasan spiritual terhadap kinerja tenaga kependidikan dari Jasour et al, (2016) serta Khandan, Eyni, \& Koohpaei (2017).

Organizational Citizenship Behavior (OCB) berpengaruh secara positif dan signifikan terhadap kinerja tenaga kependidikan. Terbukti dari koefisien struktural sebesar 0.187 , dan $p$-value 0.019 yang artinya bahwa Organizational Citizenship Behavior (OCB) yang meningkat akan secara signifikan meningkatkan kinerja tenaga kependidikan. Skor rata-rata variabel Organizational Citizenship Behavior (OCB) 3.90 (kategori tinggi) dan rata-rata variabel kinerja tenaga kependidikan 4.13 (kategori tinggi). Dapat disimpulkan bahwa jika Organizational Citizenship Behavior (OCB) tenaga kependidikannya tinggi, maka akan meningkatkan penghargaan terhadap hak-hak orang lain. Tingkat penghargaan terhadap hak-hak orang lain akan meningkatkan kinerja tenaga kependidikan. Penelitian ini mendukung penelitian sebelumnya terkait pengaruh Organizational Citizenship Behavior (OCB) terhadap kinerja tenaga kependidikan dari Yadav (2013) dan Ramadhan (2018). 
Terdapat efek mediasi parsial Organizational Citizenship Behavior (OCB) diantara kecerdasan emosional dan kecerdasan spiritual terhadap kinerja tenaga kependidikan Universitas Negeri Malang. Hal ini dibuktikan hasil analisis yang menunjukkan terdapat pengaruh tidak langsung dan signifikan antara kecerdasan emosional terhadap kinerja tenaga kependidikan melalui Organizational Citizenship Behavior (OCB) dengan koefisien (0.064). Terdapat pula pengaruh tidak langsung dan signifikan antara kecerdasan spiritual terhadap kinerja tenaga kependidikan melalui Organizational Citizenship Behavior (OCB) dengan koefisien (0.096). Karena pengaruh langsung kecerdasan emosional terhadap Organizational Citizenship Behavior (OCB) adalah signifikan dan pengaruh langsung kecerdasan spiritual terhadap Organizational Citizenship Behavior (OCB) juga signifikan, maka mediasinya adalah parsial. Hasil penelitian ini mendukung penelitian yang dilakukan oleh Andrew \& Cazares (2015), Isnaini, et al.,(2018) dan Kaori et al., (2014).

\section{Kesimpulan}

Kesimpulan dari penelitian ini adalah adanya efek mediasi parsial dari Organizational Citizenship Behavior (OCB) diantara kecerdasan emosional dan kecerdasan spiritual terhadap kinerja tenaga kependidikan. Sedangkan kecerdasan emosional, kecerdasan spiritual, dan Organizational Citizenship Behavior (OCB) masingmasing berpengaruh secara signifikan terhadap kinerja tenaga kependidikan Universitas Negeri Malang.

Adapun saran yang diberikan, antara lain sebagai berikut:

a) Universitas Negeri Malang diharapkan bisa lebih memberikan perhatian pada hal-hal yang dapat meningkatkan kecerdasan emosional, kecerdasan spiritual, dan Organizational Citizenship Behavior (OCB) karena terbukti faktor tersebut berpengaruh signifikan terhadap peningkatan kinerja;

b) Universitas Negeri Malang diharapkan bisa mempertahankan variabel apa saja yang sudah baik dan memperbaiki/ meningkatkan variabel apa saja yang masih kurang yaitu kecerdasan emosional pada indikator Others's emotion appraisal, dengan cara banyak mengadakan kegiatan penyegaran yang melibatkan tenaga kependidikan antar bagian sehingga diharapkan tingkat kemampuan dalam mempersepsikan dan mengerti emosi dari sesama tenaga kependidikan akan meningkat, serta dampaknya akan meningkatkan kinerja tenaga kependidikan; dan

c) Universitas Negeri Malang diharapkan juga bisa meningkatkan perilaku yang berkaitan dengan Organizational Citizenship Behavior (OCB) diantaranya perilaku saling menolong, menjaga hubungan baik dengan sesama tenaga kependidikan, bijaksana, memiliki kontrol diri yang bagus, dan sportif. Perilaku tersebut akan meningkatkan aspek kerjasama, komitmen dan kedisiplinan diantara tenaga kependidikan yang pada akhirnya dapat meningkatkan kinerja secara keseluruhan.

Kemudian rekomendasi untuk penelitian lebih lanjut adalah penambahan variabel lain seperti kepemimpinan transaksional/ transformasional, motivasi kerja, kepuasan kerja, komitmen dan budaya organisasi.

\section{Daftar Pustaka}

Andrew, A. S., \& Cazares, F. L. (2015). Mediating Effects of Organizational Citizenship Behavior on Organizational Performance: Empirical Analysis of Public Employees in Guadalajara, Mexico. EconoQuantum, Volume 12, Nomor 2, pp.71-92.

Anggraini, D. N. (2017). Pengaruh Kecerdasan Emosional dan Komitmen Afektif terhadap Kinerja Karyawan dengan Organizational Citizenship Behavior (OCB) sebagai Variabel Intervening (Studi kasus pada PT. Sari Warna Asli Unit 1 Karanganyar). Skripsi, Institut Agama Islam Negeri Surakarta.

Anwar, M. A. et al. (2017). Assessing Organizational Citizenship Behaviour Through Constructing Emotional Intelligence. Asia-Pacific Journal of Business Administration, Volume 9, Nomor 2, pp.105-117.

Anwar, M. A,. \& Osman-Ghani, Aa. M. (2015). The Effects of Spiritual Intelligence and its Dimensions on Organizational Citizenship Behaviour. Journal of Industrial Engineering and Management, Volume 8, Nomor 4, pp.1162-1178.

Arbuckle, J.L., \& W. Worthke. (1999). Amos 4.0 User's Guide. SmallWaters Corporation, USA.

Baron, R. M., \& Kenny, D. A. (1986). The ModeratorMediator Variable Distinction in Social The Moderator-Mediator Variable Distinction in Social Psychological Research: Conceptual, Strategic, and Statistical Considerations. Journal of Personality and Social Psychology. Volume 51, Nomor 6, pp.1173-1182.

Basu, E., Pradhan, R. K., \& Tewari, H. R. (2017). Impact of Organizational Citizenship Behavior on Job Performance in Indian Healthcare Industries: The Mediating Role of Social Capital. International Journal of Productivity and Performance Management, Volume 66, Nomor 6, pp.780-796.

Dhani, P., \& Sharma, T. (2017). Effect of Emotional Intelligence on Job Performance of IT Employees: A Gender Study. Procedia Computer Science. Vol. 122, pp. 180-185. 
Garcia, A., \& Ocampo, R. (2016). Emotional Intelligence and Conscientiousness as Predictors of Organizational Citizenship Behavior. Bedan Journal of Psychology, Volume I, pp. 62-70.

Goleman, D. (2000). Working With Emotional Intelligent. Jakarta: GramediaPustaka Utama.

Goleman, D. (2005). Kecerdasan Emosi Untuk Mencapai Puncak Prestasi, Cetakan Keenam (diterjemahkan oleh Alex Tri Kuntjahyo Widodo dari Working With Emotional Intelligence). Jakarta: PT. Gramedia Pustaka Utama.

Isnaini, F. Z., Sunuharyo, B. S., \& Aini, E. K. (2018). Pengaruh Kepuasan Kerja terhadap Kinerja Karyawan dengan Variabel Mediator Organizational Citizenship Behavior (OCB) (Studi pada Karyawan Hotel Sahid Montana Malang). Jurnal Administrasi Bisnis, Vol. 61(3), pp.100108.

Jasour, Mina., \& Maleki Avarsin, Sadegh. (2016). The Relationship between Attributional Style and Spiritual Intelligence and Job Performance of Employees of Tabriz University of Medical Education. Research and Development in Medical Education. Vol. 5 No. 2, pp.55-61.

Kaori, Res Mineke Kin., Sri Wahyu Lely Hana., \& Chairul Saleh. Pengaruh Kecerdasan Emosional dan Kecerdasan Spiritual terhadap Kinerja Pelayanan melalui Organizational Citizenship Behavior (OCB) pada PT PLN (Persero) Area Jember. Tersedia pada http://repository.unej.ac.id/bitstream/handle/1234 56789/63802/RES\%20MINEKE\%20KIN\%20KA ORI.pdf?sequence $=1$ [diakses pada 10 Februari 2019].

Khandan, M., Eyni, Z., \& Koohpaei, A. (2017). Relationship between Spirtual Intelligence and Job Performance: A Case Study of Nurses and Nursing Aids in the Main University Hospital of Qom, Iran. Health, Spirtuality and Medical Ethics, Volume 4, Nomor 3, pp.8-13.

Kinicki \& Fugate. (2013). Organizational Behavior 9th. Singapore: McGraw Hill International Edition.

Moosapour, S., \& Branch, G. (2013). Spiritual Intelligence Relationship with Organizational Citizenship Behavior of High School Teachers in Germi City. Journal of Business Management \& Social Science Research, Vol. 2(10), pp. 72-75.

Organ, D. W. (1988). Organizational Citizenship Behavior the Good Soldier Syndrome. Lexington, MA: Lexington Book.

Organ, D. W., Podsakoff, P. M., \& MacKenzie, S. B. (2006). Organizational Citizenship Behavior: Its Nature, Antecedents, and Consequences. Personnel Psychology, Vol. 59(2), pp.484-487.
Podsakoff, P., MacKenzie, S., Paine, J., \& Bachrach, D. (2000). Organizational Citizenship Behaviors: A Critical Review of The Theoretical and Empirical Literature and Suggestions For Future Research. Journal of Management, Volume 26, Nomor 3, pp.513-563.

Ramadhan, F. P. (2018). Pengaruh Organizational Citizenship Behavior (OCB) dan Good Corporate Governance (GCG) terhadap Kinerja Karyawan (Studi pada Karyawan PT. TASPEN (Persero) Kantor Cabang Malang). Jurnal Administrasi Bisnis, Volume 55, Nomor 2, pp.160-166.

Robbin, Stephen. P. (2001). Perilaku Organisasi: Konsep, Aplikasi, Terjemahan Endra, Jilid 1 Edisi 8. Jakarta: PT Prenhalindo.

Robbins, Stephen P. (2008). Organizational Behavior, Tenth Edition. Prentice Hall, New Jersey.

Yadav, P. (2013). Organisational Citizenship Behavior: A Review of Antecedent, Correlates, Outcomes and Future Research Directions. IJHPD, Vol. 2 No. 2, pp.1-19.

Zohar, Danah., \& Marshall. (2007). SQ: Spiritual Intelligence The Ultimate Intelligence. Alih Bahasa Rahmani Astuti dkk. Bandung: Penerbit Mizan Media Utama. 